\title{
Government Discretion of License Regulation in The Conversion Agricultural Land to Non Agriculture in Regional Autonomy
}

\author{
Khrisna Hadiwinata* \\ State Polytechnic of Malang, Jl. Soekarno Hatta no. 9 Malang, Jawa Timur, Indonesia \\ Shohib Muslim \\ State Polytechnic of Malang, Jl. Soekarno Hatta no. 9 Malang, Jawa Timur, Indonesia \\ Hudriyah Mundzir \\ State Polytechnic of Malang, J1. Soekarno Hatta no. 9 Malang, Jawa Timur, Indonesia
}

\begin{abstract}
Regional autonomy prefers development in the sector promising a short-term higher advantage (profit) to increase regional genuine income (PAD), but poorly takes account of public interest as a whole. This can be seen among other things from the planning of zonal spatial order (RTRW) which tends to impels agricultural-soil conversion to non-agricultural utilization, and low political will from regional government to consistently make and implement regional regulation related to agricultural-soil conversion. The obligation of land maintenance (cultivation), and to increase the fertility of the land and to protect it have been stated in article 15 of the Act No 5 of 1960 on main rule of agrarian principles complemented with criminal sanction as stated in article 52 point 1 Of UUPA, and in the Act No 41 of 2009 on PLPB. But still, law enforcement of these regulations has not been implemented as properly set. The RTRW still does not have legal sanction, and also against violation of formation rule of the RTRW supposed to have considered various aspects, among other things prevention of productive agricultural-soil conversion, especially irrigated rice field.
\end{abstract}

Keywords: Discretion, Regulation, Agricultural, regional autonomy

DOI: $10.7176 / \mathrm{JLPG} / 114-03$

Publication date:October $31^{\text {st }} 2021$

\section{INTRODUCTION}

In the concept of welfare state, the government must actively open itself to promote the welfare of the people. Franz Magnis-Suseno considering the public welfare as social prerequisite which enables and facilitates human beings to develop all their values is a condition of social life needed by every individual, family and social community for intact and fast development consisting of requirements which have to be fulfilled to achieve the welfare, so that the people has the welfare. They are free from hunger and poverty, from discouragement about their future, from anxiety, from oppression, whenever they feel that they are not needed unfairly, and so forth. It is called welfare whenever someone feels safe, peaceful, if he can live his life in accordance with his hopes and his own values, whenever he feels free to create his individual and social life in accordance with aspiration and also with possibilities which are available for him. If he feels secure and free, he can develop his potency and creativity, even though in limited condition.

Land is a valuable asset. For a nation, land plays an important role capable of indicating the national sovereignty. Taking over the land by other nation as a result from colonialism will have negative effect on the growth of economic, social and political of the country. Limited land supply, the quantity is imbalance. In the early formation of Indonesian state, national awareness has been existed that people welfare can only be brought about by government intervention. Preamble and articles of 1945 Constitution indicate that the way in which the welfare can be brought about for Indonesian people is by making the state plays its roles as director, regulation and policy maker based on Pancasila as ideology and philosophy of the state.

Indonesian law of land affairs which is part of the existing law, it basically is based on the concept of welfare state. This can be seen from the article 33 point (1-4) of 1945 Constitution; point 1: Economy is composed as concerted effort based on principle of kinship; point 2: branches of production crucial to the state and which dominate the life of people are controlled by the state; point 3: soil, water and natural abundance are dominated by the state and to be used for prosperity of the people; point 4: national economy is carried out on the basis of economic democracy with principles of togetherness, fair efficiency, continuity, vision of environment, independence, and also preserves balance of progression and national unity. As an example, article 7 of UUPA which forbids excessive land-domination, article 10 of UUPA which requires the agricultural land owner to cultivate the land actively in order to prevent blackmail, article 17 which sets minimum and maximum wide of the land owned by one family or corporation in order to create equality or evenness in land domination, and so forth. Land as main capital of development plays very important role to implement the activities of development, such as building schools, widening road, and so forth. Today, the need for land is increasing to 
fulfill various kinds of requirements to stimulate the development in the even distribution for all the people, particularly physical development in the village and city as well. Land as the main capital of development holds a very important role to carry out the activity of development, such as building schools, widening roads and so forth. But the supply is limited. The writer chose the aforementioned title because of land disputes frequently occur between groups of people who wish for justice. The measure of justice is subjective and relative. It is subjective because it is defined by human (the judge) who has an authority to decide, but he or she cannot possibly have an absolute perfection. It is relative, because it could be fair for somebody, but unfair for somebody else.

Therefore in every activity of development, it is not only the responsibility of government, but it is also requires an active role from private sector and public as well. To fulfill the need for land in the private sector and government, it is hardly likely to use the land directly owned by the state because of its limited land supply. The solution is to use the people land by granting compensation to the owners. As stated in the UUPA, in article 6, every right of land has social function. It means that the rights of land, cannot be justified, that the land will be used (or will not be used) merely for private interest, it has to be useful for the public and the country as well. But it doesn't mean that public interest will outmatch individual interest. Individual and public interest must complement each other, so that it eventually will achieve the objective of prosperity, justice and happiness for all Related to social function, it is proper that the land must be well preserved in order to increase the fertility and to prevent the damage. The obligation of land preservation is not only for the owner has to do, but also for every corporation and agency which has legal relations with the land. Regulation which sets land takeover from the people for development is enforced by way of: 1. Land procurement, i.e. every activity to get the land by compensating to those who have the right on the land; 2. Release or transfer of the rights on the land. Release is an activity of releasing the connection between the people who are entitled to and their land by giving compensation based on consensus.

As a result from the increase of population and consumption per capita stimulated by increase of household income, so the need for rice is steadily increasing. To fulfill the increasing need, national production of rice must increase adequately in order to preserve food adequacy. But various researches reveal that growth rate of rice production lately is continuously slowing down.

The deceleration is attributable to slow rate of productivity growth from the farmers because there is no technological breakthrough capable of increasing the rice productivy is significantly. Whereas experiences so far indicate that increase of rice productivity is the main variable for national rice production increase. Specific transformation from agricultural utilization to non-agricultural known as conversion is increasing along the time. In Indonesia, this phenomenon can cause serious problems, if it is not anticipated seriously from now on. The implication is uncontrolled conversion of agricultural land can threaten the capacity of food supply, and in the long run, it can result in social disadvantage

In the situation where rice production is more and more difficult to be increased because of the problem of rice field enlargement and stagnant technology, land conversion to non-agricultural utilization will exacerbate the problem of food. Therefore, controlling the rice field conversion has increasingly important role to play in order to support the food adequacy. Agricultural census revealed that in 1983-1993 agricultural land has decreased by 1.28 million ha. Land decrease is attributable to conversion of agricultural land to non-agricultural purpose, so that total decrease of agricultural soil is 2.47 million ha, whereas increase in agricultural soil as a result from the opened new areas only reached 1.19 million ha'.

\section{RESULT}

\section{Government Discretion of License Regulation in the Conversion of Agricultural Soil to Non- Agricultural In the Era of Regional Autonomy}

Land policy is based on article 33 point (3) of Constitution which is explained further in Act No 5 of 1960 (UUPA). In article 2 point (1) of UUPA, it is stated that land (earth), water and space, including natural abundance are dominated or controlled by the state. In article (2), the rights of controlling or dominating grant the authority to the state to:

1. Control utilization, supply, preserving the soil, water and space.

2. Decide and regulate legal relations between people with the earth, water, and space, and

3. Determine and regulate legal relations between people and legal acts regarding to the earth, water and space. As for "the state dominates" means that the state accepts the authority from the people to regulate the purpose, supply and utilization of the land which has to be responsible to the people. The authority of regulating by the state is curtailed by Constitution and the relevance with the goal will be achieved, i.e. prosperity of the people.

UUPA has given the basic concept of land structured."Government, in the framework of Indonesian socialism, makes a general plan of supply, purpose and utilization of earth, water and space and natural abundance:

a. For state purpose; 
b. For devotional purpose;

c. For the necessities of centers of public, social, cultural life and other welfare;

d. For the necessities of developing agricultural production, animal husbandry and fishery;

e. For developing industry, transmigration and mining.

Transformation of land purpose-structuring is not only influenced by land condition but by many other variables as well, particularly social and economic development. To control the transformation, it is carried out by regulation about instruction of land utilization. In the era of Old Order regime, this thing was regulated by Agrarian Director General Rules Number 2 year 1968 about Fatwa Tata Guna Tanah (the regulation of agrarian director general) then replaced by Peraturan Menteri Dalam Negeri Number 3 year 1978 about Fatwa Tata Guna Tanah (the regulation of the secretary of interior).

Fatwa is an objective technical assessment or evaluation and one of considerations in suggesting resolution of application on rights of land and granting the conversion license of land utilization. The content consists of condition of the land utilization, land capacity, water supply, and possible effect on the surrounding area, grand design and map of the firm, social-economic aspect of land cultivation and aspect of land structuring. Three obstacles become the reasons why regulation of controlling land conversion is difficult to be implemented, those are; (i) contradictive policies; (ii) limited coverage of the policies; (iii) consistence of planning.

Contradictive policies occur because in one hand the government is trying to forbid the conversion, but in other hand the developmental policy of industry/manufacture and other non-agricultural sector encourages the conversion of agricultural soil. Secondly, policy coverage is limited. The regulations are imposed on the firms/corporation which will be use the land and/or will carry out conversion of agricultural soil to nonagricultural. The conversion carried out individually has not been reached by the rules or regulations. The land conversion carried out individually is wide enough. Problem of plan consistence is attributable to the RTRW (Rencana Tata Ruang Wilayah) preceded with mechanism of granting the license of location are the main instruments of control to prevent the conversion of technical irrigated rice field. In fact, many RTRWs plan to carry out the conversion.

Other weaknesses in the existing regulations: (i) object of agricultural soil protected from the process of conversion is set based on physical condition of the land, but the condition is easily engineered, so that the conversion can proceed without violating any existing regulations; (ii) the existing regulations are not compulsory and there are no clear sanctions to be imposed; (iii) if the conversion occur which is not in accordance with the existing regulations, it will be difficult to find out the most responsible institution because the license to do conversion is collective decision of various agencies.

\section{CONCLUSION}

1. Regional autonomy prefers development in the sector promising a short-term higher advantage (profit) to increase regional genuine income, but poorly takes account of public interest as a whole. This can be seen among other things from the planning of zonal spatial order which tends to impels agricultural-soil conversion to non-agricultural utilization, and low political will from regional government to consistently make and implement regional regulation related to agricultural-soil conversion.

2. The weak legal system and law enforcement of the existing regulations. The obligation of land maintenance (cultivation), and to increase the fertility of the land and to protect it have been stated in article 15 of the Act No 5 of 1960 on main rule of agrarian principles complemented with criminal sanction as stated in article 52 point 1 of UUPA, and in the Act No 41 of 2009 on PLPB. But still, law enforcement of these regulations has not been implemented as properly set. The RTRW still does not have legal sanction, and also against violation of formation rule of the RTRW supposed to have considered various aspects, among other things prevention of productive agricultural-soil conversion, especially irrigated rice field.

\section{RECOMMENDATIONS}

Some recommendations regarding the issue of agricultural land trans-function to non-agricultural concretely can be done sort of efforts as follows;

1. Arrangement of regional regulation that can harmonize the interests of the government and the society. So that regional government will not give the approval of agricultural land trans-function easily, just to increase the regional income.

2. Controlling the trans-function of agricultural land to non-agriculture land should involve and rely on society participation community-based management plan by involving the active participation of stakeholders as the entry point of its planning, implementation, supervision, and Law values and the exist regulations. 
3. As soon as possible designing the draft Law on Agricultural Land Management Food Immortal ( RUU PLPPA) to be discussed, socialized and enacted immediately.

4. Revitalization of controller policy of agricultural land trans-function by pointing to the alternative policies, which are: law, economics, zoning alternatives and the social initiatives.

\section{References}

Adrian, S. (2010). Hukum Perizinan Dalam Sektor Pelayanan Publik. Jakarta: Sinar Grafika

Antonio, C. (1994). Hak Asasi Manusia di Dunia yang Berubah. Jakarta: YOI.

Artidjo, A.(2000). Negara Tanpa Hukum, Catatan Pengacara Jalanan. Yogyakarta: Pustaka Pelajar.

Dicey, A.V. (1971). An Introduction to the Study of the Law of the Constitution. London: English Language Book and Mac Millian.

Bagir, M.(2001). Menyongsong Fajar Otonomi Daerah. Yogyakarta: Penerbit Pusat Studi Hukum Fakultas Hukum UII Yogyakarta.

Bayu, S.(1980). Desentralisasi dan Dekonsentrasi Pemerintahan di Indonesia Suatu Analisa. Jakarta: Dewa Ruci Press.

Bernard, A. S. (2000). Refleksi Tentang Struktur Ilmu Hukum, sebuah Penelitian Tentang Fundasi Kefilsafatan dan Sifat Keilmuan Ilmu Hukum sebagai Landasan Keilmuan Ilmu Hukum sebagai Landasan Pengembangan Ilmu Hukum Nasional Indonesia. Bandung: Mandar Maju.

Bhenyamin, H. (2005). "Hubungan Kewenangan Pusat dan Daerah" dalam Soetandyo Wignjosoebroto, dkk, 2005. Pasang Surut Otonomi Daerah: Sketsa Perjalanan 100 Tahun. Jakarta: Yayasan Tifa dan ILD.

Brian, Z. T. (2006). On The Rule Of Law: History, Politics, Theory. Cambridge University Press.

Boedi, H. (2005). Hukum Agraria Indonesia, Sejarah Pembentukan Undang-Undang Pokok Agraria Isi dan Pelaksanaannya. Jakarta: Penerbit Djambatan.

Catarina, K. (2001). "Hak Atas Kepemilikan" dalam Asbjorn Eide, dkk (editor), 2001. Hak Ekonomi, Sosial dan Budaya. Jakarta: Departemen Hukum \& HAM berkerjasama dengan Sida. Crosby, B. L. (1992). Stakeholder Analysis: A Vital Tool for Strategic Managers. Technical Notes, No.2. Agency for International Development, Washington DC.

Kansil, C. S. T. (1986). Hukum Antar Tata Pemerintahan (Comparative Government). Erlangga, Jakarta.

Utrecht, E. (1957). Pengantar dalam Hukum Indonesia. Jakarta: Ichtiar.

Elly, R. (2015). Akutnya Konversi Lahan Pertanian, Kompas, 19 Desember 2015.

Entang, S. (2016). Dilema Konversi Lahan, Pikiran Rakyat, 19 Agustus 2016.

Gerry, S. (1991). The Politics of Local Government. London: McMillan dalam Hanif.

Nurcholish, (2007). Teori dan Praktik Pemerintahan dan Otonomi Daerah. Jakarta: Grasindo

Gunawan, W. (1984). Pola Penguasaan Tanah dan Reforma Agraria. Dalam S.M.P. Tjondronegoro dan G.Wiradi (eds). Dua abad Penguasaan Tanah : Pola Penguasaan Tanah-Pertanian di Jawa dari Masa ke Masa. Jakarta: Yayasan Obor Indonesia dan PT. Gramedia.

Hamid, S. A. (2004). "Teori Perundang-undangan Indonesia, Suatu sisi Ilmu Pengetahuan Perundang-undangan Indonesia yang Menjelaskan dan Menjernihkan Pemahaman" Pidato diucapkan pada upacara Pengukuhan Jabatan Guru Besar Tetap pada FH UI Jakarta tanggal 25 April 1992, dalam Hendra Nurtjahjo (editor), 2004. Politik Hukum Tata Negara Indonesia, Jakarta: Pusat Studi HTN FH UI.

H. J. Romein dalam Ridwan HR, (2002). Hukum Administrasi Negara. Yogyakarta: UII Press.

I Made Arya Utama, (2007). Hukum Lingkungan: Sistem Hukum Perizinan Berwawasan Lingkungan Untuk Pembangunan Berkelanjutan. Bandung: Pustaka Sutra.

Imam, K. (2002). Hukum Tata Ruang dan Tata Guna tanah. Handout kuliah, tidak diterbitkan

Imam, S. \& Thohari, A. A. (2004). Dasar-dasar Politik Hukum. Jakarta: PT. Raja Grafindo Persada.

Indroharto, (1999). Usaha Memahami UU PTUN (buku 1) Beberapa Pengertian Dasar Hukum Tata Usaha Negara. Jakarta: Sinar Harapan.

Bruggink, J. J. H. (1996). Refleksi Tentang Hukum. Bandung: Citra Aditya Bakti.

Irawan, (2005). Konversi Lahan sawah: Potensi dampak, pola pemanfaatannya, dan factor determinan. Agro Ekonomi, Jurnal, Bogor.

Isa.I. (2006). Strategi Pengendalian Alih Fungsi Tanah Pertanian. Makalah pada Seminar Multifungsi (Multifunctionality of Agriculture). Bogor, 27-28 Juni 2006. Balai Besar Sumberdaya Lahan (BBSDL), Ministry of Agriculture, Fisheries, and Forestry (MAFF) of Japan, dan ASEAN Secretariat. Bogor.

Masyhur, E. (2005). Perkembangan Dimensi Hak Asasi Manusia (HAM) \& Proses Dinamika Penyusunan Hukum Hak Asasi Manusia (Hakham). Ciawi, Bogor: Ghalia Indonesia.

Mukthie, F.(2006). "Pergeseran Paradigma Ilmu Pengetahuan" Hand Out Kuliah PDIH Universitas Brawijaya Malang.

Mukthie, F. (1996). Beberapa Masalah Pembangunan Hukum dan Hukum Pembangunan, Penerbit Fakultas Hukum Universitas Brawijaya, Malang. 
Republik Indonesia, Constitution of the Republic of Indonesia on 1945.

Republik Indonesia, Government Regulation 2004 No.16 on Land Utilization.

Republik Indonesia, Law 1960 No. 5 on Agrarian Principle Basic Regulation.

Republik Indonesia, Law 1997 No.23 on Nature Management.

Republik Indonesia, Law 2000 No. 25 on National Establishment Program 2000-2004.

Republik Indonesia, Law 2007 No. 26 on Urban Planning.

Republik Indonesia, Law 2009 N0. 41 on Food Land and Sustainable Agriculture. 